\title{
Characterization of care provided at a Speech Therapy School Clinic affiliated with the Brazilian public healthcare system
}

\author{
Isadora Katariny Monteiro de Sousa Farias ${ }^{1}$ \\ https://orcid.org/0000-0002-4958-7944 \\ Ana Nery Barbosa de Araújo ${ }^{1}$ \\ https://orcid.org/0000-0001-7887-6246 \\ Cynthia Maria Barboza do Nascimento ${ }^{1}$ \\ https://orcid.org/0000-0001-9197-2136 \\ Ivana Arrais de Lavor Navarro Xavier ${ }^{1}$ \\ https://orcid.org/0000-0001-8142-8364 \\ Mirella Bezerra Rodrigues Vilela1 \\ https://orcid.org/0000-0001-5113-7144
}

Universidade Federal de Pernambuco UFPE, Departamento de Fonoaudiologia, Recife, Pernambuco, Brasil.

Conflict of interests: Nonexistent

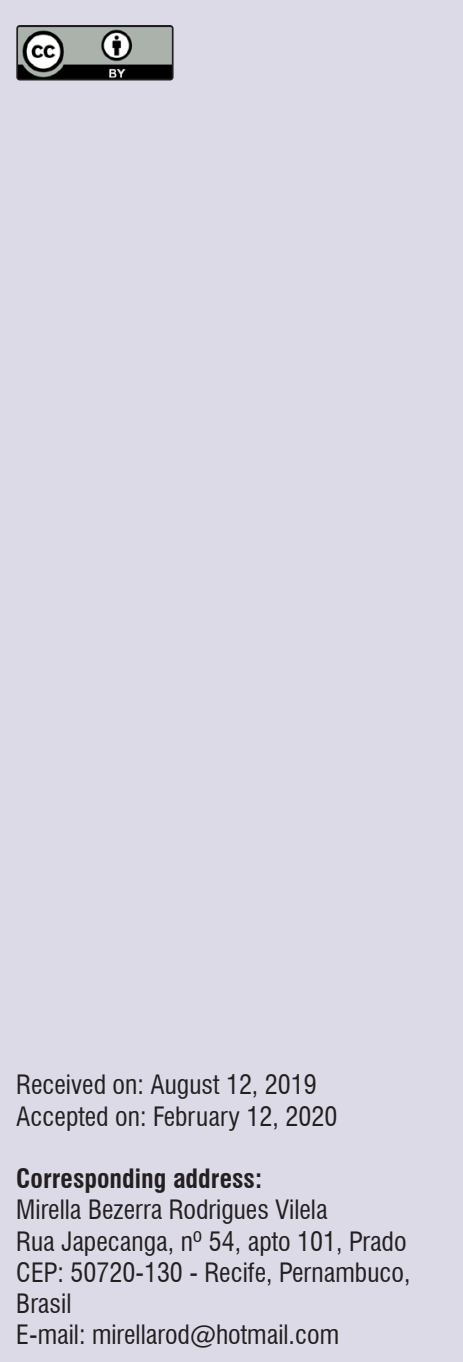

\section{ABSTRACT}

Objective: to characterize the care provided at a speech therapy school clinic affiliated with the Brazilian public healthcare system, in 2016.

Methods: a cross-sectional study was conducted with data from screening, discharge, discontinuation and medical records. Sociodemographic and clinical variables were assessed, by measuring waiting time and specialty. The reasons for treatment discontinuation were also investigated. The data were presented in tables and expressed as absolute and relative frequencies.

Results: one hundred-seven individuals were screened, among whom $53.3 \%$ were children, $58.9 \%$ were males, $41.1 \%$ had language complaints and $35.5 \%$ had complaints regarding orofacial motor function. The mean waiting time to begin treatment was 6.6 months. Among all individuals screened, $80.3 \%$ began treatment. The treatment, more frequently, addressed orofacial motor function (39.1\%) and language (37.9\%). Discharge from treatment occurred in $28.6 \%$ of cases. Among the 37 individuals whose treatment was discontinued prior to completion, the main reason was abandonment/absences on the part of the patient (71.4\%).

Conclusion: the speech therapy care profile revealed a greater frequency of children, males and needs regarding language and orofacial motor function. The mean waiting time was 6.6 months and $20 \%$ of the individuals screened did not initiate treatment. A high frequency of discontinuation prior to completing treatment was found, due, mainly, to failure on the part of the patients to attend the sessions.

Keywords: Speech, Language and Hearing Sciences; Epidemiology; Prevalence; Public Health Services; Delivery of Health Care 


\section{INTRODUCTION}

The Brazilian public healthcare system is the result of a broad health reform movement that began in the $1970 \mathbf{s}^{1,2}$. Universal healthcare is recognized as a right of the population as well as a duty of the Brazilian government, as stipulated in the 1988 federal constitution $^{3}$. The public healthcare system must perform coordinated actions involving health promotion, disease prevention and rehabilitation ${ }^{4}$.

Its organizational structure is founded on doctrinal principles and guidelines ${ }^{5,6}$. Regionalization is one such principle, the purpose of which is to ensure the organized offer of health actions on all levels of care ${ }^{7,8}$. A healthcare network organized and planned considering the demands of a region enables the creation of coordinated strategies of health promotion, disease prevention and rehabilitation based on the needs of the population ${ }^{9}$. Thus, the organization and functioning of services should consider the demands of patients determined through an analysis of the epidemiological and sociodemographic profile of these patients. It is in this context that the discussion on healthcare models is broadened ${ }^{10}$. According to Paim ${ }^{11}$, a care model uses diverse resources with distinct purposes to meet the needs of a community and organizes healthcare services according to the epidemiological profile of this community.

Health information systems unite data on human communication health, which is to the acquisition of information regarding the needs in the field of speech therapy ${ }^{12}$. However, the incipience of such information hinders knowledge on the demand and sociodemographic characteristics of the public in need of such services, which has negative repercussions regarding the planning and organization of healthcare networks.

Epidemiological studies provide knowledge on demands for treatment, which contributes to the establishment of effective public policies ${ }^{13}$. However, few population-based studies have measured the prevalence of speech/language problems ${ }^{14-16}$. In this respect, the databanks produced by healthcare services can be useful in the planning and management of health care as well as the establishment of public policies. Therefore, the aim of the present study was to characterize the profile of care offered at a speech therapy school clinic affiliated with the Brazilian public healthcare system, in 2016.

\section{METHODS}

This study received approval from the Human Research Ethics Committee of the Federal University of Pernambuco (certificate number: 2106639). A crosssectional study was conducted at a speech therapy school clinic of a public university located in the city of Recife, Brazil. The clinic was inaugurated in 2013 and is registered with the National Registry of Health Establishments as a service that offers mediumcomplexity care in the Brazilian public healthcare system. It functions as a teaching clinic guided by the three pillars of the university (teaching, research and extension), providing speech therapy to all age groups of the population, and has a technical cooperation accord with the Municipal Secretary of Health of the city of Recife, the aim of which is to offer speech therapy services on an outpatient basis. The clinic has 10 examining rooms, three clinical supervision rooms, three hearing therapy rooms, a coordination room, a multimedia room as well as voice and computer laboratories. The therapeutic itinerary of the clinic is as follows: the patient is initially submitted to screening, the scheduling of which is regulated by the public healthcare system (SISREG), and is then placed on a waiting list. When an appointment becomes available in the specialty the patient requires, the clinic contacts the patient by telephone to begin treatment, at which time the patient's chart is created.

The data were collected in 2017. The year 2016 was selected for the cross-sectional study, which was the last complete year for which information was available at the time of data collection. As the accord with the public healthcare system was signed in 2015, the data from 2016 reflect the actual situation of the clinic.

One hundred-seven screening forms were examined. Among the patients invited to undergo speech therapy after screening, the discharge, discontinuation and medical records were also evaluated.

Data collection was performed using a chart addressing the following sociodemographic, general and clinical data: age, sex, schooling, occupation, municipality of residence, treatment specialty, diagnosis, time on the waiting list prior to speech therapy, care status and reason for discontinuing care. The diagnostic hypothesis was collected from the specific box on the screening form. As this constituted a list of possible diagnoses selected during screening, when complementary exams are yet to be requested and referrals to other health professionals are yet to be made, the list of hypotheses spanned a 
broad spectrum. Thus, a more generic classification was used for this variable. For example, the functional, organic and organofunctional categories of dysphonia were grouped into a single category (dysphonia) for which the evaluation of an otolaryngological evaluation and complementary exams may be needed. Thus, the researchers grouped the hypotheses in a way that remained faithful to the records.

The Epilnfo software, version 3.4.5, was used for the creation, processing and analysis of the databank. The data were presented in tables and expressed as absolute and relative frequencies.

\section{RESULTS}

Among the 107 individuals screened at the clinic, $53.3 \%$ were younger than 10 years of age, $58.9 \%$ were males, $38.8 \%$ had studied up to elementary school and $32 \%$ had only a preschool education. Regarding occupation, $85.3 \%$ were students. Although the clinic receives individuals from various municipalities of the state of Pernambuco, nearly all patients (94\%) were residents of municipalities located in the metropolitan region of Recife (Table 1).

Table 1. Description of sociodemographic characteristics of individuals screened at a speech therapy school clinic, Recife, Brazil, 2016.

\begin{tabular}{|c|c|c|}
\hline VARIABLE & $\mathrm{N}$ & $\%$ \\
\hline \multicolumn{3}{|l|}{ Age aroup } \\
\hline Less than 10 years & 57 & 53.30 \\
\hline 10 to 19 years & 17 & 15.90 \\
\hline 20 to 39 years & 16 & 15.00 \\
\hline 40 to 59 years & 12 & 11.20 \\
\hline 60 years or older & 5 & 4.70 \\
\hline Total & 107 & 100.00 \\
\hline \multicolumn{3}{|l|}{ Sex } \\
\hline Males & 63 & 58.90 \\
\hline Females & 44 & 41.10 \\
\hline Total & 107 & 100.00 \\
\hline \multicolumn{3}{|l|}{ Schooling } \\
\hline None & 1 & 1.00 \\
\hline Preschool & 33 & 32.00 \\
\hline Elementary school & 40 & 38.80 \\
\hline High school & 11 & 10.70 \\
\hline University & 16 & 15.50 \\
\hline Postgraduate degree & 2 & 1.90 \\
\hline Not informed & 4 & 4.00 \\
\hline Total & 107 & 100.00 \\
\hline \multicolumn{3}{|l|}{ Occupation } \\
\hline Administrator & 1 & 1.00 \\
\hline Retired & 2 & 2.00 \\
\hline Homemaker & 5 & 4.90 \\
\hline Student & 87 & 85.30 \\
\hline Military serviceman & 1 & 1.00 \\
\hline Educator & 2 & 2.00 \\
\hline Mason & 1 & 1.00 \\
\hline Professor & 3 & 3.00 \\
\hline Not informed & 5 & 5.00 \\
\hline Total & 107 & 100.00 \\
\hline \multicolumn{3}{|l|}{ Municipality of residence } \\
\hline Metropolitan Region of Recife & 97 & 94.00 \\
\hline Coastal zone & 6 & 4.00 \\
\hline Semi-arid interior & 3 & 2.00 \\
\hline Not informed & 1 & 1.00 \\
\hline Total & 107 & 100.00 \\
\hline
\end{tabular}


Regarding the different fields of speech therapy, most of the complaints were related to language $(41.1 \%)$ and orofacial motor function (35.5\%). Phonetic deviation and phonologic deviation stood out among the diagnostic hypotheses (each accounting for 12.9\%) and dysphonia accounted for $11.88 \%$ (Table 2).

Table 2. Clinical characteristics of individuals screened at a speech therapy school clinic, Recife, Brazil, 2016.

\begin{tabular}{lcc}
\hline VARIABLE & N & $\%$ \\
\hline Treatment specialty & 44 & 41.10 \\
Language & 38 & 35.50 \\
Orofacial motor function & 25 & 23.40 \\
Voice & 107 & 100.00 \\
Total & & \\
\hline Diagnostic hypothesis & 13 & 12.90 \\
Phonetic deviation & 13 & 12.87 \\
Phonological deviation & 12 & 11.88 \\
Dysphonia & 8 & 7.92 \\
Phonetic and phonological deviation & 7 & 6.93 \\
Language delay & 7 & 6.90 \\
Vocal improvement & 7 & 6.90 \\
Orofacial myofunctional disorder & 6 & 6.00 \\
Language disorder & 5 & 5.94 \\
Language disorder secondary to autism spectrum disorder & 5 & 5.00 \\
Stuttering & 5 & 3.00 \\
Obstructive sleep apnea syndrome and snoring & 2 & 2.00 \\
Phonetic deviation and mouth breathing & 2 & 2.00 \\
Learning disorder & 2 & 2.00 \\
Dysarthria and dysphagia & 2 & 1.00 \\
Dysfluency and phonological deviation & 1 & 1.00 \\
Vocal improvement and orofacial myofunctional disorder & 1 & 1.00 \\
Dysphonia and orofacial myofunctional disorder & 1 & 1.00 \\
Dysphonia and dysphagia & 1 & 1.00 \\
Phonetic deviation and orofacial myofunctional disorder & 1 & 1.00 \\
Phonological deviation and mouth breathing & 1.00 \\
Mouth breathing & 1 & 1.00 \\
Snoring and mouth breathing & 1.00 \\
Tachylalia & 1 & 100.00 \\
\hline
\end{tabular}

Among the individuals screened, $49.4 \%$ remained on the waiting list for up to six months $(X=6.6$ months; $\mathrm{Md}=$ seven months; $\delta=4.1$ months) and $80.3 \%$ began speech therapy. The specialties that most called patients from the waiting list were orofacial motor function $(39.10 \%)$ and language (37.9\%). Discharge from treatment occurred in $28.6 \%$ of cases and treatment was discontinued in $32.4 \%$ of cases. The main reason $(71.4 \%)$ for discontinuing treatment was abandonment/failure on the part of the patient to attend the sessions (Table 3). 
Table 3. Characteristics of follow-up at a speech therapy school clinic, Recife, Brazil, 2016.

\begin{tabular}{lcc}
\hline VARIABLE & $\mathbf{N}$ & $\%$ \\
\hline Called to begin treatment & 87 & 81.30 \\
Yes & 20 & 18.70 \\
No & 107 & 100.00 \\
Total & 43 & 49.40 \\
\hline Time after screening & 35 & 40.20 \\
Up to six months & 9 & 10.30 \\
7 months to one year & 87 & 100.00 \\
More than one year & & \\
Total & 34 & 39.10 \\
\hline Specialty & 33 & 37.90 \\
Orofacial motor function & 20 & 23.00 \\
Language & 87 & 100.00 \\
Voice & & \\
Total & 86 & 80.30 \\
\hline Treatment started & 16 & 14.70 \\
Yes & 102 & 100.00 \\
No & & \\
Total & 72 & 80.70 \\
\hline Treatment continued & 13 & 14.30 \\
No & 85 & 100.00 \\
Yes & & \\
Total & 35 & 28.60 \\
\hline If not continued, reason & 37 & 32.40 \\
Discharge & 72 & 100.00 \\
Discontinuation & & \\
Total & 25 & 71.40 \\
\hline Reason for discontinuation & 4 & 100.00 \\
Abandonment/absences & 2 & \\
Scheduling conflict & 4 & \\
Change of address & 35 & \\
Other & & \\
Total & 30 \\
\hline & 30 & \\
\hline
\end{tabular}

\section{DISCUSSION}

The findings of the present study show that more than a half of the individuals screened for speech therapy were children and males. Although some studies report no considerable differences in prevalence between sexes ${ }^{17}$, most indicate that problems with human communication are more frequent among males $^{18,19}$. With regard to age, studies show that speech problems are common among children less than 10 years old $^{20,21}$. Other studies associated language problems and problems with orofacial motor function in children less than 10 years of age, correlating these problems with $\mathrm{sex}^{22,23}$. Problems with human communication in schoolchildren can exert a negative influence on child development, social aspects and academic performance ${ }^{24,25}$.

Studies report that socioeconomic aspects and schooling are strongly associated with child development ${ }^{17,26,27}$. Children whose parents have a low level of schooling may be more prone to the deprivation of stimuli, which could exert a negative impact on learning and the development of language ${ }^{26}$. A study conducted with nine children in a hospital in São Paulo found an association between schooling and oral habits capable of causing speech, otolaryngologic and dental problems ${ }^{27}$.

Regarding the different fields of speech therapy, human communication problems were related more to language, orofacial motor function and voice. Some 
studies in the literature report that problems with language are more prevalent ${ }^{28,29}$, followed by orofacial motor function ${ }^{28}$, which is consistent with the present results.

To express oneself verbally in an intelligible manner, besides developing the phonological aspect, the phonetic aspect has to be balanced. For such balance, the oral organs need to be in harmony. An abnormality in any of the structures involved can exert an influence on speech, leading to the need for intervention to correct the problem ${ }^{16}$.

Studies report that the high frequency of problems related to orofacial motor function may be related to harmful oral habits, such as bottle feeding, the use of a pacifier or nonnutritive sucking habits as well as a diet consisting exclusively of pasty foods. These aspects can contribute to problems involving the stomatognathic system ${ }^{30,31}$.

By analyzing the frequency of diagnostic hypotheses, a greater proportion of phonetic deviation and phonological deviation was found, followed by dysphonia. The mean frequency of phonological deviation reported in the literature is $13.9 \%^{32,33}$, which is close to the frequency found in the present study.

Regarding the capacity of the clinic to receive those on the waiting list for speech therapy after screening, more than $80 \%$ of the individuals began treatment. This indicates the efficacy of the care offered at the clinic, with a good standard of access to the service. Among the individuals called in for treatment, more than half waited for up to six months after screening. In a study conducted in the state of Bahia at another teaching clinic, the aim of which was to analyze the patient profile and time on the waiting list, the average time until the onset of treatment was six months ${ }^{16}$. School clinics meet the considerable demands of the population with low economic power, a large portion of whom are referred by primary care services.

Although some studies indicate a large number of individuals on waiting lists for speech therapy ${ }^{31}$, a study conducted at a care center affiliated with the public healthcare system in the city of Cascavel in the state of Paraná, Brazil, found that $40.9 \%$ of patients were not placed on waiting lists and $13.63 \%$ were on the waiting list for up to six months, due to out of order equipment in the period in which they were scheduled for auditory testing ${ }^{34}$. This finding is likely due to the fact that hearing exams are performed in a prompt manner and patients do not need to remain in continuous, systematic care.
Orofacial motor function was the specialty to which more individuals were called from the waiting list, whereas language was the specialty for which the patients spent a longer time waiting for the onset of treatment. Among those called to begin speech therapy, only about $15 \%$ failed to appear to begin treatment, demonstrating that most patients were unable to find treatment at other services during the time in which they were on the waiting list.

A study conducted in the city of Maceió, capital of the state of Alagoas, Brazil, showed problems of accessibility to healthcare services, which may be related to the offer of activities, the scheduling of appointments, office hours, the criteria for selecting cases, the waiting time and transportation ${ }^{32}$, which compromises the offer and utilization of healthcare services.

Treatment needed to be discontinued in approximately one-third of cases. The major reason (accounting for $70 \%$ of cases) was abandonment/failure on the part of the patients to show up for the sessions. A study conducted at a speech therapy clinic of the Federal University of Minas Gerais, at Belo Horizonte, MG, Brazil, also found excessive absences to be the main reason for discontinuing treatment ${ }^{35}$. Adherence to treatment is fundamental to therapeutic progress. Therefore, the active, cooperative engagement of the patients who seek treatment is necessary.

A study conducted at a primary care service in the city of Campinas, SP, Brazil, reported that many patients abandoned speech therapy due to scheduling incompatibility, the care dynamics, the observation of an improvement or resolution of the case, a lack of patient motivation and the need to undergo treatment in another field ${ }^{36}$. In the present study, non-compliance may have been related to the expectation on the part of the patients to obtain discharge from therapy in a short period of time. However, as a teaching clinic, the flow of care is slower, since the sessions are performed by students, which probably translates to slower procedures, as interns do not have the same skills as professional speech therapists. Thus, the slow progress may discourage patients, leading them to abandon treatment.

The present study provides knowledge on the profile of individuals screened for speech therapy and the frequency of specific problems involving human communication at the clinic analyzed. The authors recognize that the cross-sectional design does not enable a perfect characterization of the scenario over time. However, all screening forms at the clinic 
throughout a one-year period (2016) were analyzed. These findings could contribute not only on the local scale to the planning/monitoring/management of this healthcare service, but also serve as reference for other services that provide speech therapy in the public health realm.

\section{CONCLUSION}

The profile of patients screened at the speech therapy clinic revealed a greater frequency of children, males and needs regarding language and orofacial motor function. The mean waiting time was 6.6 months and $20 \%$ of the individuals screened did not initiate treatment. A high frequency of discontinuation, prior to completing treatment, was found, due mainly, to failure on the part of the patients to attend the sessions. The present findings could assist in the planning of speech therapy actions, contribute to the organized offer of healthcare services and serve as a reference for future studies.

\section{REFERENCES}

1. Paiva CHA, Teixeira LA. Reforma sanitária e a criação do Sistema Único de Saúde: notas sobre contextos e autores. Hist. cienc. saudeManguinhos. 2014;21(1):15-35.

2. Ferla $A A$, Maranhão $T$, Rocha $C M F$, Peixoto GP, Silva IFD, Barrios SG et al. As histórias das vivências e estágios no Sistema Único de Saúde em seus múltiplos cenários. In: Ferla AA, Maranhão T, Rocha CMF (orgs). Múltiplos cenários do VER-SUS: vivências e estágios de Norte a Sul do Brasil. Porto Alegre: Editora Rede Unida; 2016, 1 edição, vol 2. p.8-10.

3. Brasil. Constituição (1990). Constituição da República Federativa do Brasil. Brasília, DF: Senado Federal: Centro Gráfico. 1988.

4. Fernando AITH, Budjoso Y, Nascimento PR, Dallari SG. Os princípios da universalidade e integralidade do SUS sob a perspectiva da política de doenças raras e da incorporação tecnológica. Rev. Direito Sanit. 2014;15(1):10-39.

5. Gil CRR, Luiz Cl, Gil MCR. Gestão publica e saúde: contexto de implantação e aspectos organizacionais da gestão do SUS. São Luiz: EDUFMA, 2016, 1 edição.

6. Kalichman AO, Ayres JRCM. Comprehensiveness and healthcare technologies: a narrative on conceptual contributions to the construction of the comprehensiveness principle in the Brazilian Unified National Health System. Cad.Saúde Pública. 2016;32(8):e00183415.

7. Carvalho ALB, Jesus WLA, Senra IMVB. Regionalization in the SUS: implementation process, challenges and perspectives in the critical view of system managers. Ciênc. saúde coletiva. 2017;22(4):1155-64.

8. Brasil. Ministério da Saúde (MS). Manual de planejamento no SUS. Brasília: MS; 2016.

9. Fertonani HP, Pires DEP, Biff D, Scherer MDA. The health care model: concepts and challenges for primary health care in Brazil. Ciênc. saúde coletiva. 2015;20(6):1869-78.

10. Netto L, Silva KL, Santos MR. Desenvolvimento de competências para promoção da saúde e mudança no modelo assistencial. Texto Contexto Enferm. 2016;25(2): e2150015.

11. Paim J, Travassos C, Almeida C, Nahia L, Macinko J. O sistema de saúde brasileiro: história, avanços e desafios. Lancet (Série Brasil). 2011;11-31.

12. Caceres JV, Pacheco AB, Fedosse E, Mello JG. The potentiality of the basic health care information system for actions in speech-language pathology. Rev. CEFAC. 2014;16(5):1723-9.

13. Longo IA, Tupinelli GG, Hermógenes $C$, Ferreora LV, Molini-Alvejonas DR. Prevalence of speech and language disorders in children in the western region of São Paulo. CoDAS. 2017;29(6): e20160036.

14. Jardim DS, Maciel FJ, Lemos SMA. Epidemiological profile of a hearing-impaired population. Rev. CEFAC. 2016;18(3):746-57

15. Di Ninno CQMS, Fonseca LFN, Pimenta MVE, Vieira ZG, Fonseca JA, Miranda ICC et al. Levantamento epidemiológico dos pacientes portadores de fissura de lábio e/ou palato de um centro especializado de Belo Horizonte. Rev. CEFAC . 2011;13(6):1002-8.

16. Costa RG, Souza LBR. Perfil dos usuários e da demanda pelo serviço da clínica-escola de fonoaudiologia da UFBA. R. Ci. méd. biol. 2009;8(1):53-9.

17. Samelli AG, Rondon-Melo S, Rabelo CM, MoliniAvejonas DR. Association between language and hearing disorders - risk identification. Clinics. 2017;72 (4):213-7.

18. Alves JMM, Carvalho AJA, Pereira SCG, Escarce AG, Goulart LMHF, Lemos SMA. Association between language development and school environment in children of early childhood education. Distúrb. Comun. 2017;29(2):342-53. 
19. Rabelo ATV, Campos FR, Friche CP, Silva BSV, Friche AAI, Alves CRL et al. Speech and language disorders in children from public schools in Belo Horizonte. Rev. paul. pediatr. 2015;33(4):453-9.

20. Bartz DW, Laux CN, Peruch CV, Ferreira MID, Machado MS, Ribas LP. Relationship between masking level difference test and acoustic reflex findings in children with phonological disorder. Rev. CEFAC. 2015;17(5):1499-508.

21. Cardoso MH, Romero ACL. Alterações de processos fonológicos e índice de gravidade em uma amostra de fala e de escrita de escolares de ensino público e privado. Rev. psicopedag. 2018;33(102):283-93.

22. Caldeira HJM, Antunes SLNO, Rossi-Barbosa LAR, Freitas DA, Barbosa MR, Caldeira AP. Prevalence of speech disorders in children through screening test. Rev. CEFAC. 2013;15(1):144-52.

23. Campos FR, Rabelo ATV, Friche CP, Silva BS, Friche $A A L$, Alves $C R L$ et al. Oral language disorders in children from 4 to 6 years old in Belo Horizonte. Rev. CEFAC. 2014;16(4):1151-60.

24. Cardoso MH, Romero ACL. Alterações de processos fonológicos e índice de gravidade em uma amostra de fala e de escrita de escolares de ensino público e privado. Rev. psicopedag. 2018;33(102):283-93.

25. Caldeira HJM, Antunes SLNO, Rossi-Barbosa LAR, Freitas DA, Barbosa MR, Caldeira AP. Prevalence of speech disorders in children through screening test. Rev. CEFAC. 2013;15(1):144-52.

26. Carniel CZ, Furtado MCC, Vicente JB, Abreu RZ, Tarozzo RM, Cardia SETR et al. Influence of risk factors on language development and contributions of early stimulation: an integrative literature review Rev. CEFAC. 2017;19(1):109-18.

27. Longo IA, Tupinelli GG, Hermógenes C, Ferreora LV, Molini-Alvejonas DR. Prevalence of speech and language disorders in children in the western region of São Paulo. CoDAS. 2017;29(6):e20160036

28. Campos FR, Rabelo ATV, Friche CP, Silva BS, Friche AAL, Alves CRL col. Oral language disorders in children from 4 to 6 years old in belo horizonte. Rev. CEFAC. 2014;16(4):1151-60.

29. Silva GMD, Couto MIV, Avejonas DRM. Risk factors identification in children with speech disorders: pilot study. CoDAS. 2013;25(5):456-62.

30. Mandra PP, Diniz MV. Characterization of the diagnostic profile and flow of a Speech-Language Pathology service in child language within a public hospital. Rev. soc. bras. fonoaudiol. 2011;16(2):121-5.

31. Corrêa CC, Arakawa AM, Maximino LP. Speech, language and hearing teaching-clinic: waiting list management. Rev. CEFAC. 2016;18(5):1222-9.

32. Lima BPS, Guimarães JATL, Rocha MCG. Características epidemiológicas das alterações de linguagem em um centro fonoaudiológico do primeiro setor. Rev. soc. bras. fonoaudiol. 2008;13(4):376-80.

33. Siqueira LAO, Katia MH. Accessibility to speech therapy care in service of mean complexity. Rev. CEFAC. 2015;17(2):461-74.

34. Cunha JT, Massi G, Guarinello AC, Pereira FM. SUS users' perception: a speech-language pathology approach based on health promotion. CoDAS. 2016;28(4):417-28.

35. Marques SRL, Friche AAL, Motta AR. Adesão à terapia em motricidade orofacial no ambulatório de Fonoaudiologia do Hospital das Clínicas da Universidade Federal de Minas Gerais. Rev. soc. bras. fonoaudiol. 2010;15(1):54-62.

36. Paro CA, Vianna NG, Lima MCMP. Investigating the compliance with speech therapy service in the context of primary care. Rev. CEFAC. 2013;15(5):1316-24. 